\title{
Hepatitis B virus infection profile in hemodialysis patients in Central Brazil: prevalence, risk factors, and genotypes
}

\author{
Renata C Ferreira, Sheila A Teles*, Márcia A Dias, Viviane R Tavares, Simonne A Silva, \\ Selma A Gomes**, Clara FT Yoshida** Regina MB Martins/ ${ }^{+}$
}

Instituto de Patologia Tropical e Saúde Pública *Faculdade de Enfermagem, Universidade Federal de Goiás, Caixa Postal 131, 74605-050 Goiânia, GO, Brasil **Departamento de Virologia, Instituto Oswaldo Cruz-Fiocruz, Rio de Janeiro, RJ, Brasil

Hemodialysis patients are at high risk for hepatitis B virus (HBV) infection. A survey was conducted in the hemodialysis population of the state of Goiás, Central Brazil, aiming to assess the prevalence of HBV infection, to analyse associated risk factors, and also to investigate HBV genotypes distribution. A total of 1095 patients were interviewed in 15 dialysis units. Serum samples were screened for HBV serological markers by enzyme-linked immunosorbent assay. Hepatitis B surface antigen (HBsAg) positive samples were tested for HBV DNA by polymerase chain reaction and genotyped by restriction fragment length polymorphism. Global HBV infection prevalence was 29.8\% (95\% CI: 27.1-32.5). Multivariate analysis of risk factors showed that male gender, length of time on hemodialysis, and blood transfusion before 1993 were associated with HBV positivity. HBV DNA was detected in $65.4 \%(17 / 26)$ of the HBsAg-positive samples. Thirteen of 17 HBV DNA positive samples were genotyped. Genotype $D(61.5 \%)$ was predominant, followed by A (30.8\%), while genotype F was detected in only one (7.7\%) sample.

Key words: hepatitis B virus - hemodialysis - Central Brazil

Hepatitis B remains a significant worldwide health problem. Globally, it is estimated that 2 billion people have been infected, and more than 350 million people are hepatitis B virus (HBV) chronic carriers. These chronically infected individuals are at high risk of liver cirrhosis and hepatocellular carcinoma. HBV isolates have been classified into eight genotypes (A to $\mathrm{H}$ ) which have a characteristic geographical distribution (McMahon 2005).

As the parenteral exposure is a major route for viral transmission, hemodialysis patients are at particular risk of acquiring HBV infection. In some countries, this infection has been controlled in dialysis centers by adherence to hemodialysis-specific infection-control practices and to hepatitis B vaccination (Ambuhl et al. 2000, Finelli et al. 2005). However, for others, HBV infection is still an important problem to patients (Vladutiu et al. 2000, Otedo et al. 2003, Kumar et al. 2005). Nevertheless, HBV infection outbreaks are still seen when failures in infection control procedures occur (De Castro et al. 2000, Lewis-Ximenez et al. 2001).

In Brazilian hemodialysis patients, HBV infection has been poorly investigated. Few studies have shown HBsAg prevalence rates ranging from 4 to $15.1 \%$ in hemodialysis patients (Cendoroglo Neto et al. 1995, Souza et al. 2003). The present study is the first to evaluate the $\mathrm{HBV}$ infection prevalence in a large hemodialysis population in Central Brazil, which included all dialysis units and patients in the state of Goiás. Risk factors associated with this infection and HBV genotypes distribution were also

\footnotetext{
Financial support: Sectec, CNPq

${ }^{+}$Corresponding author: rbringel@terra.com.br

Received 10 March 2006

Accepted 5 July 2006
}

determined.

This study was carried out in all dialysis units $(\mathrm{N}=15)$ from the state of Goiás. Between April and December 2002, all chronic hemodialysis patients $(\mathrm{N}=1095)$ were interviewed for possible risk factors to $\mathrm{HBV}$ infection. The studied population ranged in age from 3 to 97 years (average 49.3 years). Six hundred forty-six were males (59\%) and 449 were females (41\%). During the survey period, all subjects received treatment three times a week and they were distributed in three shifts. Hemodialysis has been performed with bicarbonate and cuprophane or polysulphone dialyzers. These and bloodlines were disinfected and reused by the same patient. Hemodialysis machines were disinfected at the end of the day, and environmental surfaces after each session. HBsAg positive patients were isolated in a separated room. Permission for carrying out the study was granted by the institutions involved and informed consent was obtained from all participants. The protocol used in the present study was approved by the Ethical Committee of the Federal University of Goiás.

Serum samples were screened by enzyme-linked immunosorbent assay (ELISA) for the presence of hepatitis B surface antigen (HBsAg), hepatitis B core antibody (anti-HBc), and hepatitis B surface antibody (anti-HBs) (Hepanostika Uni-form Organon Teknika B.V., Boxtel, Holland). HBsAg-positive samples were submitted to hepatitis $\mathrm{B}$ e antigen ( $\mathrm{HBeAg}$ ) and antibody for HBeAg (anti$\mathrm{HBe}$ ) detection (Hepanostika Uni-form), and also to DNA extraction. Pre-S/S genome region was amplified by a seminested PCR assay essentially as described by MottaCastro et al. (2005). PCR products were subjected to RFLP genotyping analysis (Araujo et al. 2004).

Chi-square test and Chi-square for trend were undertaken to evaluate risk factors associated with HBV infection (defined as anti-HBc and/or HBsAg positivity). Statistical significance was assessed at the 0.05 probability level in all analyses. Risk factors, first estimated by odds 
ratio in univariate analysis, were analyzed subsequently by multiple logistic regression to identify possible confounders. Statistical evaluations were performed using Epiinfo program, version 2000 package developed by the Centers for Disease Control and Prevention (Atlanta, GA).

Of the 1095 hemodialysis patients, $272(24.8 \%)$ had anti-HBs with anti-HBc, $28(2.5 \%)$ were anti-HBc alone, and $26(2.4 \%)$ were HBsAg-positive (one had only this marker and $25 \mathrm{HBsAg}$ with and anti-HBc), resulting in an overall HBV prevalence infection of $29.8 \%$ (95\% CI: 27.1 32.5). The prevalence of anti-HBc by dialysis unit is shown in the Figure, which varied from $19.6 \%$ (Unit 7) to $41 \%$ (Unit 5). HBsAg-positive patients were distributed in eight units. Of these, Units 4 and 12 showed high HBsAg prevalence rates ( 7.5 and $6.9 \%$, respectively).

Among all risk factors studied, multivariate analysis revealed that only gender, history of blood transfusion

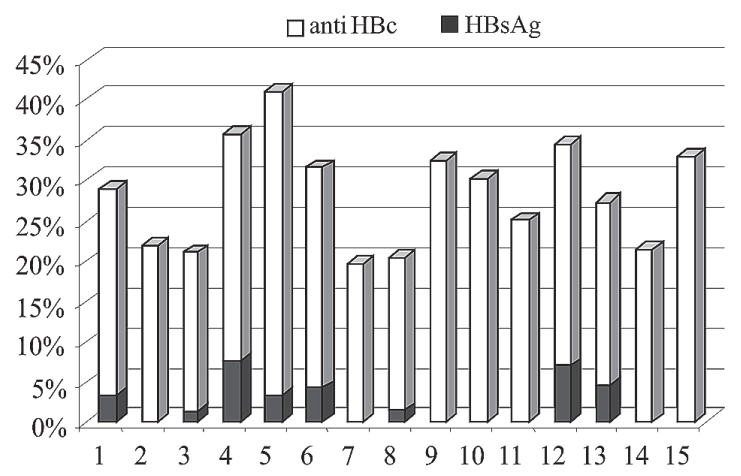

The prevalence of anti-HBc and HBsAg in 15 hemodialysis units in the state of Goiás, Central Brazil. before 1993, and length of time on hemodialysis were significantly associated with HBV positivity (Table I).

Table II shows the serological and molecular characteristics of the HBsAg-positive hemodialysis patients. Nine (34.6\%) subjects were HBeAg-positive, 15 (57.7\%) were anti-HBe-positive, and the remaining $2(7.7 \%)$ were negative for both markers. HBV DNA was detected in 9/9 (100\%) HBeAg-positive serum samples, in 7/15 (46.7\%) anti-HBe-positive samples, and also in one sample that was negative for both markers. Among $17 \mathrm{HBV}$ DNA positive sera, genotyping was performed on 13 samples: 8 $(61.5 \%)$ were genotype D, $4(30.8 \%)$ genotype A, and 1 $(7.7 \%)$ genotype $\mathrm{F}$, whereas the remaining 4 were weakly positive by PCR. HBV isolates of genotype $\mathrm{D}$ were found in dialysis Units 4, 5, and 12. Genotype A was circulating in Units 1, 4, and 5. One sample of genotype $\mathrm{F}$ was also detected in the Unit 5.

The present study showed higher prevalence rates for the overall HBV infection and HBsAg in hemodialysis patients in Central Brazil, when compared to rates found in local blood donors (29.8 vs $10.7 \%$ and 2.4 vs $0.8 \%$, respectively) (Martelli et al. 1999). Nevertheless, a significant decline (12 to 5.8\%) was observed in the hemodialysis population of Goiânia city between 1995 and 1999 (Teles et al. 2002). Also, in this study, the prevalence declined to $2.4 \%$ in 2002 (data not shown). With reference to other Brazilian hemodialysis populations, HBsAg prevalence found in Central Brazil was lower than those observed in Tocantins (4\%) (Souza et al. 2003) and Santa Catarina (10\%) (Carrilho et al. 2004) in North and South regions, respectively, and also in Belo Horizonte (4.4\%) (Busek et al. 2002), Rio de Janeiro (11.1\%) (Vanderborght et al. 1995), and São Paulo (15.1\%) (Cendoroglo Neto et al. 1995) in Southeast of Brazil. However, these HBsAg prevalence rates were

TABLE I

Risk factors associated with hepatitis B virus infection in hemodialysis population of the state of Goiás, Central Brazil

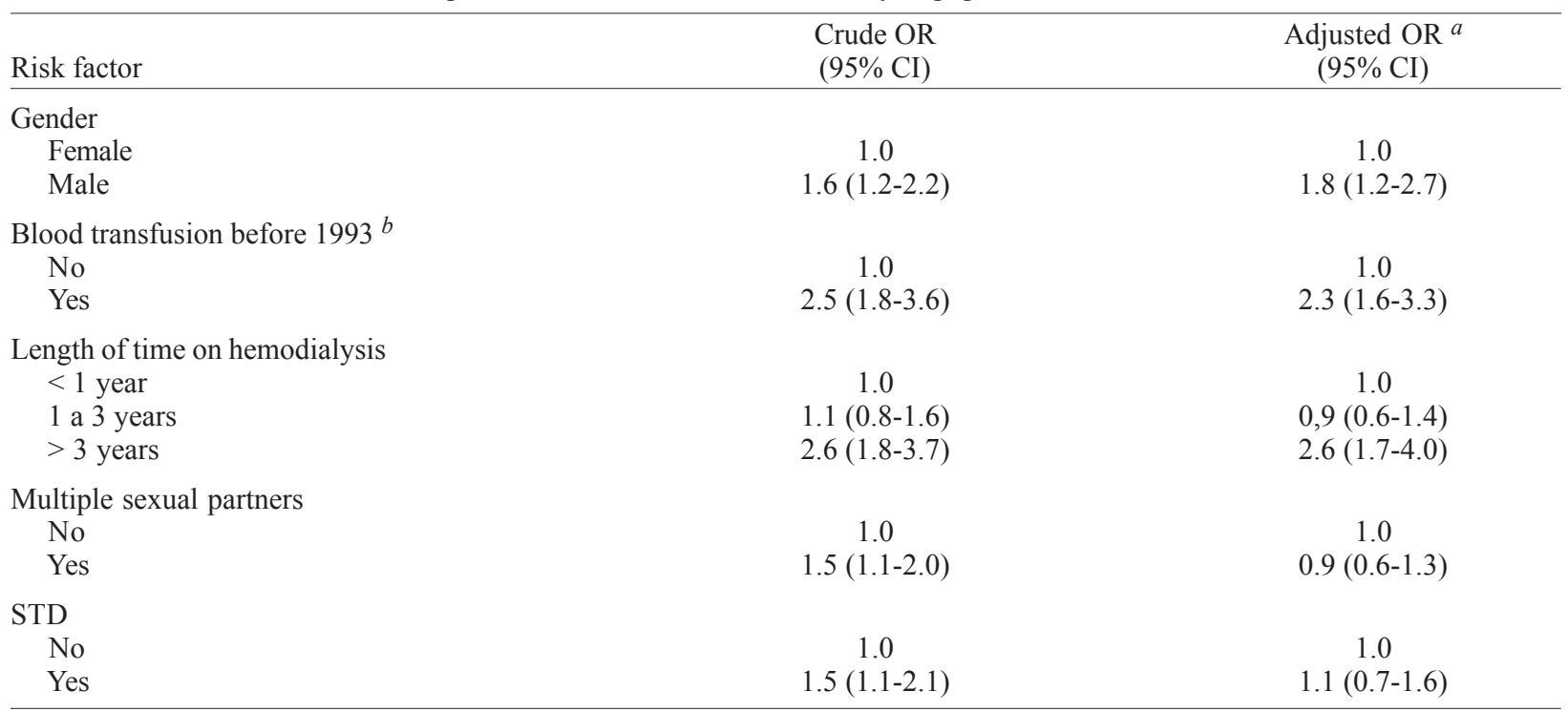

CI: confidence interval; $a$ : adjusted for age, gender, screening of blood for anti-HBc, length of time on hemodialysis, multiple sexual partners and sexually transmitted disease (STD); $b$ : the year that mandatory screening for anti-HBc was implemented in Brazil. 
TABLE II

Serological and molecular data of the hepatitis B surface antigen positive samples

\begin{tabular}{lcccc}
\hline Patient (unit) & HBeAg & Anti-HBe & HBV DNA & Genotype \\
\hline $1(1)$ & + & - & + & A \\
$2(4)$ & + & - & + & D \\
$3(4)$ & + & - & + & D \\
$4(4)$ & + & - & + & D \\
$5(4)$ & + & - & + & A \\
$6(5)$ & + & - & + & A \\
$7(5)$ & + & - & + & A \\
$8(12)$ & + & - & + & D \\
$9(12)$ & + & - & + & D \\
$10(1)$ & - & + & - & - \\
$11(3)$ & - & + & - & - \\
$12(4)$ & - & + & + & $\mathrm{D}$ \\
$13(4)$ & - & + & $+/-$ & $\mathrm{ND}$ \\
$14(4)$ & - & + & - & - \\
$15(5)$ & - & + & + & $\mathrm{D}$ \\
$16(5)$ & - & + & + & $\mathrm{F}$ \\
$17(5)$ & - & + & $+/-$ & $\mathrm{ND}$ \\
$18(5)$ & - & + & - & - \\
$19(6)$ & - & + & $+/-$ & $\mathrm{ND}$ \\
$20(6)$ & - & + & - & - \\
$21(6)$ & - & + & - & - \\
$22(6)$ & - & + & - & - \\
$23(13)$ & - & + & $+/-$ & $\mathrm{ND}$ \\
$24(13)$ & - & + & - & - \\
$25(4)$ & - & - & + & $\mathrm{D}$ \\
$26(8)$ & - & - & - & - \\
\hline
\end{tabular}

ND: non determined; HBeAg: hepatites Be antigen; anti-HBe: antibody for $\mathrm{HBeAg}$.

higher than those found in developed countries as Switzerland (1.6\%) (Ambuhl et al. 2000) and the US (1\%) (Finelli et al. 2005). These data show that HBV infection continues to be an important problem in Brazilian dialysis units.

Blood transfusion has been pointed as an important risk factor for hepatitis B in hemodialysis population (Vladutiu et al. 2000, Otedo et al. 2003). In the present investigation, patients who received blood transfusion before 1993 had a 2.3 -fold (95\% CI: 1.6.-3.3) greater risk of HBV positivity compared to those that were transfused after. Screening of blood products for HBsAg and antiHBc in Brazilian blood banks since 1989 and 1993, respectively, has been contributed to reduce this risk (Kupek 2001). In addition, the use of recombinant erythropoietin for anemia treatment has decreased the need for blood transfusion in hemodialysis patients.

Many investigations have demonstrated that duration of hemodialysis treatment is strictly correlated with hepatitis B positivity, suggesting HBV nosocomial transmission (Vladutiu et al. 2000, Busek et al. 2002, Otedo et al. 2003, Carrilho et al. 2004). In fact, our patients under treatment for more than three years had 2.6-fold (95\% CI: 1.74.0) greater risk of HBV infection compared to subjects who had undergone less than one year.

HBV DNA was detected in serum samples of all (9/9) HBeAg-positive patients and in $46.7 \%(7 / 15)$ of the anti$\mathrm{HBe}$-positive patients. One $\mathrm{HBe} \mathrm{Ag} /$ anti-HBe-negative patient also had HBV DNA detectable in his serum. These data were similar to those previously found by Teles et al. (2002), which emphasize the need for rapid recognition and isolation of HBsAg-positive patients regardless of their $\mathrm{HBeAg} /$ anti-HBe status.

HBV isolates of genotypes A, D and F were detected in the studied patients. These genotypes have been found in other Brazilian hemodialysis populations (De Castro et al. 2000, Teles et al. 2002, Souza et al. 2003, Carrilho et al. 2004) reflecting the HBV genotypes circulating in our country (Moraes et al. 1996, Araujo et al. 2004, Sitnik et al. 2004). Genotype D was predominant in this hemodialysis patients $(61.5 \%)$, as observed by others (De Castro et al. 2000, Teles et al. 2002, Carrilho et al. 2004). In addition, $\mathrm{HBV}$ isolates from genotype $\mathrm{D}$ have been involved in outbreak in dialysis units (De Castro et al. 2000). These findings suggest that genotype D is more likely to disseminate in hemodialysis environmental. In fact, this genotype was more frequently found in Units 4 and 12 where high HBsAg prevalence rates were observed. In these units, all patients $(2-4,8,9,12$, and 25$)$ infected with genotype D had more than 3 years on hemodialysis and did not dialyzed in another unit before.

In conclusion, although HBsAg prevalence in hemodialysis population of Goiás, Central Brazil, is smaller than those found in other Brazilian hemodialysis patients, it is still high when compared with those observed in developed countries. The finding that length of time on hemodialysis is associated with HBV seropositivity suggests nosocomial transmission. Also, the predominance of genotype D of HBV in this population corroborates this hypothesis, reinforcing the need for stricter adherence to infection control measures in dialysis units. Therefore, further studies with genome sequencing may provide more detail information on the molecular epidemiology of HBV infection, which may be helpful in understanding the HBV transmission in this hemodialysis population.

\section{ACKNOWLEDGEMENTS}

To the patients and staff of the hemodialysis units of the state of Goiás. To Megmar AS Carneiro, Adriane S Gomes, Nádia RS Reis, and Nara R Freitas, for their collaboration in this study.

\section{REFERENCES}

Ambuhl PM, Binswanger U, Renner EL 2000. Epidemiology of chronic hepatitis B and C among dialysis patients in Switzerland. Schweiz Med Wochenschr 130: 341-348.

Araujo NM, Mello FCA, Yoshida CFT, Niel C, Gomes SA 2004. High proportion of subgroup A' (genotype A) among Brazilian isolates of hepatitis B virus. Arch Virol 149: 13831395.

Busek SU, Babá EH, Tavares Filho HA, Pimenta L, Salomão A, Corrêa-Oliveira R, Oliveira GC 2002. Hepatitis C and hepatitis $\mathrm{B}$ virus infection in different hemodialysis units in Belo Horizonte, Minas Gerais, Brazil. Mem Inst Oswaldo Cruz 97: 775-778.

Carrilho FJ, Moraes CR, Pinho JRR, Mello IMVGC, Bertolini DA, Lemos MF, Moreira RC, Bassit LC, Cardoso RA, Ribeiro-dos-Santos G, Da Silva LC 2004. Hepatitis B virus infection in hemodialysis centers from Santa Catarina State, 
Southern Brazil. Predictive risk factors for infection and molecular epidemiology. BMC Public Health 4: 13.

Cendoroglo Neto M, Draibe SA, Silva AEB, Ferraz ML, Granato C, Pereira CAP, Sesso RC, Gaspar AMC, Ajzen H 1995. Incidence of and risk factors for hepatitis $\mathrm{B}$ virus and hepatitis $\mathrm{C}$ virus infection among haemodialysis and CAPD patients: evidence for environmental transmission. Nephrol Dial Transplant 10: 240-246.

De Castro L, Araujo NM, Sabino RR, Alvarenga F, Yoshida CFT, Gomes SA 2000. Nosocomial spread of hepatitis B virus in two hemodialysis units, investigated by restriction fragment length polymorphism analysis. Eur J Clin Microbiol Infect Dis 19: 531-537.

Finelli L, Miller JT, Tokars JI, Alter MJ, Arduino MJ 2005. National surveillance of dialysis-associeted diseases in the United States, 2002. Semin Dial 18: 52-61.

Kumar D, Arora A, Singh NP, Kohli R, Kar P, Das BC 2005. Hepatitis $G$ virus infection in hemodialysis patients from urban Delhi. Ren Fail 27: 87-93.

Kupek EJ. 2001. Residual transfusion risk for hepatitis B and C in southern Brazil, 1991-99. J Viral Hepat 8: 78-82.

Lewis-Ximenez LL, Oliveira JM, Mercadante LAC, De Castro L, Santa Catharina W, Stuver S, Yoshida CFT 2001. Serological and vaccination profile of hemodialysis patients during an outbreak of hepatitis B virus infection. Nephron 87: 19-26.

Martelli CMT, Turchi MD, Souto FJ, Sáez-Alqézar A, Andrade ALSS, Zicker F 1999. Anti-HBc testing for blood donations in areas with intermediate hepatitis B endemicity. Rev Panam Salud Publica 6: 69-73.

McMahon BJ 2005. Epidemiology and natural history of hepatitis B. Semin Liver Dis 25: S3-S9.

Moraes MTB, Gomes SA, Niel C 1996. Sequence analysis of
pre-S/S gene of hepatitis B virus strains of genotypes A, D, and F isolated in Brazil. Arch Virol 141: 1767-1773.

Motta-Castro ARC, Martins RMB, Yoshida CFT, Teles SA, Paniago AM, Lima KMB, Gomes AS 2005. Hepatitis B virus infection in isolated Afro-Brazilian communities. $J$ Med Virol 77: 188-193.

Otedo AE, Mc'Ligeyo SO, Okoth FA, Kayima JK 2003. Seroprevalence of hepatitis B and C in maintenance dialysis in a public hospital in a developing country. $S$ Afr Med $J$ 93: 380-384.

Sitnik R, Pinho JRR, Bertolini DA, Bernardini AP, Silva LC, Carrilho FJ 2004. Hepatitis B virus genotypes and precore and core mutants in Brazilian patients J Clin Microbiol 42: $2455-2460$.

Souza KP, Luz JA, Teles SA, Carneiro MAS, Oliveira LA, Gomes AS, Dias MA, Gomes SA, Yoshida CFT, Martins RMB 2003. Hepatitis B and C in the hemodialysis unit of Tocantins, Brazil: serological and molecular profiles. Mem Inst Oswaldo Cruz 98: 599-603.

Teles SA, Martins RMB, Gomes SA, Gaspar AMC, Araujo NM, Souza KP, Carneiro MAS, Yoshida CFT 2002. Hepatitis B virus transmission in Brazilian hemodialysis units: serological and molecular follow-up. $J$ Med Virol 68: 4149.

Vanderborght BOM, Rouzere C, Ginuino CF, Maertens G, Van Heuverswyn H, Yoshida CFT 1995. High prevalence of hepatitis $\mathrm{C}$ infection among Brazilian hemodialysis patients in Rio de Janeiro: a one-year follow-up study. Rev Inst Med Trop São Paulo 37: 75-79.

Vladutiu DS, Cosa A, Neamtu A, State D, Braila M, Gherman M, Patiu IM, Dulau-Florea I 2000. Infections with hepatitis $\mathrm{B}$ and $\mathrm{C}$ viruses in patients on maintenance dialysis in Romania and in former communist countries: yellow spots on a blank map? J Viral Hepat 7: 313-319. 